was high in all groups, respondents were told only that the survey was to gather health information, and many patients were unaware of their specific diagnosis at the time of interview. Furthermore, all the subjects in this analysis acknowledged themselves to be smokers. There may have been some gaps in the smoking histories as we do not know how often patients stopped smoking between changes in brand or while smoking a single brand. By comparing age at interview with age at start of smoking habit plus time since giving up plus years of use we estimated that $17690(97 \%)$ of the subjects who had smoked had done so continuosuly or with a total smoking free interval of two years or less. Another limitation was that the questionnaire recorded no more that four different brands of cigarettes. The procedures that were used for those smoking five or more brands would have tended to underestimate exposure, particularly the duration of use. The rarity of this occurrence, however, argued against any appreciable impact on patterns of risk.

In summary, our results suggest that reducing the risk of developing lung cancer induced by cigarette smoking in middle aged and older smokers requires primary emphasis on stopping the smoking habit or lowering the amount smoked each day. Smoking only filter brands was also associated with a lowered risk (although changing from a non-filter to a filter cigarette had only a relatively small impact on risk of developing lung cancer) but was not as effective a preventive measure as giving up completely.
We thank Dr E Benhamou, Dr J F Fraumeni Jr, Dr R Hoover, Dr E Riboli, Dr C Vutuc, and Mr D Hole for advice on the analysis of these data.

\section{References}

${ }^{1}$ US Department of Health, Education, and Welfare. Smoking and health: a report of the advisory committee to the Surgeon General of the Public Health Service. US Dhington DC: Government Printing Ofice, 1964:387.

US Department of Health, Education, and Welfare. Smoking and health: a report of the

${ }^{3}$ US Department of Health, Education, and Welfare. The health consequences of smoking for women: a report of the Surgeon General. Washington DC: Governsmoking for women: a report of the
ment Printing Office, 1970:359.

- US Department of Health and Human Services. The health consequences of smoking. The changing cigarette: a report of the Surgeon General. Washington DC: Government Printing Office, 1981:252.

${ }^{5}$ US Department of Health and Human Services. The health consequences of smoking. Cancer: a report of the Surgeon General. Washington DC: Government Printing Office, $1982: 322$.

${ }^{6}$ Lubin JH, Blot WJ, Berrino F, et al. Patterns of lung cancer risk among filter and nonfilter cigarette smokers. Int $\mathcal{f}$ Cancer (in press).

Gart JJ. Point and interval estimation of the common odds ratio in the combination of $2 \times 2$ tables with fixed marginals. Biometrika 1970;57:471-5.

Mantel $N$. Chi-square test with one degree of freedom: extension of the MantelHaenszel

reslow NE, Day NE, Halvorsen KT, Prentice RL, Sabai C. Estimation of multiple relative risk functions in matched case-control studies. Am $\mathcal{f}$ Epidemiol 1978;108:299-307.

$10 \mathrm{Lubin} \mathrm{JH}$. A computer program for the analysis of matched case-control studies. Comparative Biomedical Research 1981;14:138-43.

"Doll R, Peto R. Mortality in relation to smoking: 20 years' observations on male British doctors. Br Med $\mathcal{F} 1976 ;$ ii:1525-36.

(Accepted 9 April 1984)

\title{
The difficult choice of treatment for poorly controlled maturity onset diabetes: tablets or insulin?
}

\author{
I PEACOCK, R B TATTERSALL
}

\begin{abstract}
Patients with maturity onset diabetes that is poorly controlled on maximal doses of oral hypoglycaemic agents are difficult to treat. A prospective randomised crossover study was performed in 58 predominantly non-obese patients on maximal doses of glibenclamide or metformin, or both, to find out if insulin would improve control or well being. The patients were given daily injections of up to 48 units of highly purified porcine lente insulin. Glycaemic control was improved by $15 \%$ or more in only 18 patients; 14 others felt better but their diabetes was no better controlled. Those whose control was improved by insulin could not be distinguished by age, duration of diabetes, body mass index, or their own treatment preference. C peptide concentrations, however, did help predict the response to insulin, the fasting $C$ peptide to glucose ratio being considerably lower in those patients whose control was better on insulin.
\end{abstract}

These findings suggest that a simple insulin regimen

Derbyshire Royal Infirmary, Derby DEı $2 Q Y$

I PEACOCK, MRCP, senior medical registrar

University Hospital, Queens Medical Centre, Nottingham

R B TATTERSALL, MD, FRCP, consultant physician

Correspondence to: Dr R B Tattersall. does not necessarily lead to better glycaemic control in maturity onset diabetes. Nevertheless, a trial of insulin is often justified since it poses few practical difficulties and makes some patients feel better even if their control is not improved. A more complex regimen might improve control in more cases, but it might also be less acceptable to older patients.

\section{Introduction}

At first sight treatment of maturity onset diabetes seems simple. The basis is diet, especially for overweight patients. When this fails a sulphonylurea or a biguanide is added, or a combination of the two if either alone does not achieve good control. Finally, "when oral agents are used and found to be ineffective, either initially or secondarily, insulin should be substituted"1-the implication being that all will then be well.

In practice treatment of maturity onset diabetes is less straightforward. It is hard to change eating habits, and dietary advice is often ignored. Many patients progress to oral hypoglycaemic agents (subsequently referred to as "tablets") but still remain poorly controlled. Both doctor and patient may be reluctant to accept that tablet treatment has failed and move on to insulin. This reluctance may be justified since there is no evidence that insulin treatment necessarily produces better control of maturity onset diabetes. Indeed, there are many patients whose control appears to be worse on insulin, perhaps not surprisingly because maturity onset diabetes is a complex and heterogenous disorder resulting from insulin resistance as well as insulin deficiency. ${ }^{2-4}$ 
We undertook a prospective randomised crossover trial to compare diabetic control on insulin with that on maximal doses of oral hypoglycaemic agents. We also wanted to find out which treatment patients preferred and, if possible, to identify those likely to benefit from insulin.

\section{Patients and methods}

From hospital records we found 90 maturity onset diabetics, not prone to ketosis, who had been treated with moderate or high doses of oral hypoglycaemics for at least two years, and we asked them to take part in a study to find out if insulin would be better. Nineteen did not want to take part, and we excluded 13 others who were found during the run in period to be well controlled (fasting blood glucose less than $6 \mathrm{mmol} / \mathrm{l}(108 \mathrm{mg} / 100 \mathrm{ml})$ ) on $10 \mathrm{mg}$ glibenclamide per day or less. The remaining 35 men and 23 women had a mean age of 58 years (range $31-78$ ), mean duration of known diabetes nine years (range 2-20), and mean body mass index $23.9 \mathrm{~kg} / \mathrm{m}^{2}$ (range 17.9-29.0). Thirteen had a body weight greater than $120 \%$ of ideal. ${ }^{5}$ All gave informed written consent.

\section{STUDY DESIGN}

A run in period of at least three months was used to explain the aims and methods of the study, to practise procedures, and to improve diabetic control on tablets. During this time patients were seen monthly by a doctor and a dietitian. All patients were switched to glibenclamide before breakfast and before the main evening meal. The dose of glibenclamide was increased and metformin added, if necessary, until the fasting blood glucose concentration fell below $6 \mathrm{mmol} / 1(108 \mathrm{mg} / 100 \mathrm{ml})$, side effects occurred, or maximum doses were reached (glibenclamide $20 \mathrm{mg}$ and metformin $2 \mathrm{~g}$ daily).

When the best possible control on tablets had been achieved, patients were randomly allocated to continue tablets in the doses being taken at the end of the run in period or to take insulin (highly purified porcine zince suspension, Monotard MC) once daily. The starting dose of insulin was 12 to 16 units daily. This was increased by 4 units each week until: (a) most urine tests before breakfast showed no glucose, (b) hypoglycaemic symptoms occurred, or (c) the daily dose reached 48 units. We made further adjustments to the dose at clinic visits using the results of home blood glucose monitoring. When weight gain was excessive the insulin dose was kept below 48 units and further restriction of food recommended. As with tablets, the aim of treatment was a fasting blood glucose value less than $6 \mathrm{mmol} / \mathrm{l}(108 \mathrm{mg} / 100 \mathrm{ml})$.

DIET

All patients had been given dietary advice at the time of diagnosis, although subsequently the advice had varied. During the run in period, eating habits were reviewed and the importance of avoiding refined carbohydrates and reducing excess weight was re-emphasised. No dietary changes were made when patients switched to insulin.

During the study patients' diets were assessed by asking them to record everything eaten and drunk (using household measures) for one week before clinic visits, twice during the run in period, and then at the end of each treatment period. The diaries were discussed with the dietitian to clarify ambiguities. Food items were coded and the diet analysed using a computer program based on reference food tables. ${ }^{6}$

\section{ASSESSMENT}

Patients continued urine testing for their own guidance. In addition, they were taught to measure capillary blood glucose with Reflotest strips (Boehringer Mannheim). On three days in the week before each clinic visit blood glucose concentrations were measured before and two hours after meals and at bedtime. Strips were labelled and kept in their airtight lightproof container for reading at the clinic with a Reflomat meter. ${ }^{7}$ The average reading over the three days was taken as mean blood glucose.

Mean blood glucose at home, fasting blood glucose at the clinic, haemoglobin $A_{1}$, body weight, and fasting $C$ peptide were recorded after four and six months of each treatment. Blood glucose at clinic visits was measured by Trinder's glucose oxidase method on an autoanalyser (Technicon). ${ }^{8}$ Total haemoglobin $A_{1}$ was determined by microcolumn ion exchange chromotography (Biorad Laboratories). Our reference range for non-diabetics was $4.9 \%$ to $9.0 \%$. C peptide was measured by a modification of Heding's radioimmunological method $^{9}$ using antisynthetic human $C$ peptide guinea pig serum M1230 (Novo Research Institute, Copenhagen). Samples taken during insulin and tablet treatment were assayed together (in duplicate). The intrabatch and interbatch coefficients of variation averaged $3.2 \%$ and $7 \cdot 0 \%$ respectively.

For each individual the average change in fasting blood glucose, mean blood glucose, and haemoglobin $A_{1}$ during the run in period was determined. The same calculation was used to compare the level of diabetic control achieved during the six month control period on tablets with that on insulin. A fall of more than $15 \%$ was defined as "improved control," and a rise of more than $15 \%$ was termed "worse control." Smaller differences were classified as "no change." The statistical significance of differences between group results was assessed by Student's $t$ test (two tailed) for paired or unpaired data where appropriate. Correlation was assessed by the Spearman rank test where data were normally distributed.

At the end of the study patients were given a questionnaire asking which treatment they preferred and why.

\section{Results}

During the run in period glycaemic control improved; mean fasting blood glucose fell from $12 \cdot 1$ to $11.0 \mathrm{mmol} / 1$ (218 to $200 \mathrm{mg} /$ $100 \mathrm{ml})(\mathrm{p}<0.05)$ and mean blood glucose from 11.8 to $9.5 \mathrm{mmol} / \mathrm{l}$ (212 to $171 \mathrm{mg} / 100 \mathrm{ml})(\mathrm{p}<0.05)$. The change in haemoglobin $A_{1}$ lagged behind (table I). By the criterion of $15 \%$ change, control improved in 20 patients, was no different in 32, and was worse in six. Only nine patients reached the target fasting blood glucose value of $6 \mathrm{mmol} / 1(108 \mathrm{mg} / 100 \mathrm{ml})$ or less.

At the end of the run in period 33 patients were on maximum doses of tablets (glibenclamide $20 \mathrm{mg}$ and metformin $2 \mathrm{~g}$ daily). Four patients achieved the target fasting blood glucose concentration on doses of glibenclamide between 10 and $20 \mathrm{mg}$ daily, while 11 were treated with less than $20 \mathrm{mg}$ glibenclamide because of a tendency to hypoglycaemia during the day despite a fasting blood glucose concentration greater than $6 \mathrm{mmol} / \mathrm{l}(108 \mathrm{mg} / 100 \mathrm{ml})$. The remaining 10 patients took $20 \mathrm{mg}$ glibenclamide alone because of side effects of metformin.

Six patients did not complete the study. One died from myocardial infarction one month after starting insulin. Three asked to go back to tablets after one to three months on insulin, one because of dislike of injections, one because of non-specific malaise, and one because of symptomatic worsening of control despite 48 units of insulin. Two patients who completed six months on insulin during the first treatment period felt so ill when put back on tablets that they asked to resume insulin, after four days and one month.

During the crossover study the mean level of control was unchanged from that at the end of the run in period. Furthermore, when all the patients were considered as a single group there was no significant difference $(p>0.05)$ between control achieved on tablets and on insulin, whether assessed by fasting blood glucose at clinic visits, mean blood glucose at home, or haemoglobin $A_{1}$ (table $I$ ). Data for the group as a whole, however, conceal the fact that individual patients responded quite differently to insulin. In 18 patients control was better on insulin, 19 were better controlled on tablets, and in the remaining 18 the difference was less than $15 \%$. Improvement on insulin could not be predicted from age, duration of diabetes, or body mass index, but those whose control was improved by insulin had considerably higher blood glucose concentrations on tablets than those whose control deteriorated on insulin (table II).

After six months' treatment with insulin the mean daily dose was 30.6 units (range 12-48). Nine patients reached the maximum dose of 48 units, of whom three had better and five worse control than on tablets. Of the 54 patients who completed six months on insulin, 43 put on weight, with a mean increase of $4.2 \mathrm{~kg}$ and a maximum of $13 \mathrm{~kg}$. Weight increased even in 12 of the 19 patients whose control deteriorated on insulin.

Daily carbohydrate intake was higher on insulin (mean $183 \mathrm{~g}$, range 80-298) than on tablets (mean $177 \mathrm{~g}$, range 59-291); total energy intake was also higher on insulin (mean $7 \cdot 8 \mathrm{MJ}(1885 \mathrm{kcal}$ ), range $4 \cdot 1-11 \cdot 4 \mathrm{MJ}(974-2722 \mathrm{kcal}))$ than on tablets $(7 \cdot 5 \mathrm{MJ}(1801 \mathrm{kcal})$, range $3 \cdot 8-11.5 \mathrm{MJ}(917-2758 \mathrm{kcal}))$, but these differences were not statistically significant ( $p>0.05$ ). Carbohydrate intake averaged $40 \%$ of total energy but for individual patients the range was $27-52 \%$. 
TABLE I-Mean diabetic control and weight during run in and treatment periods. Ranges are shown in parentheses

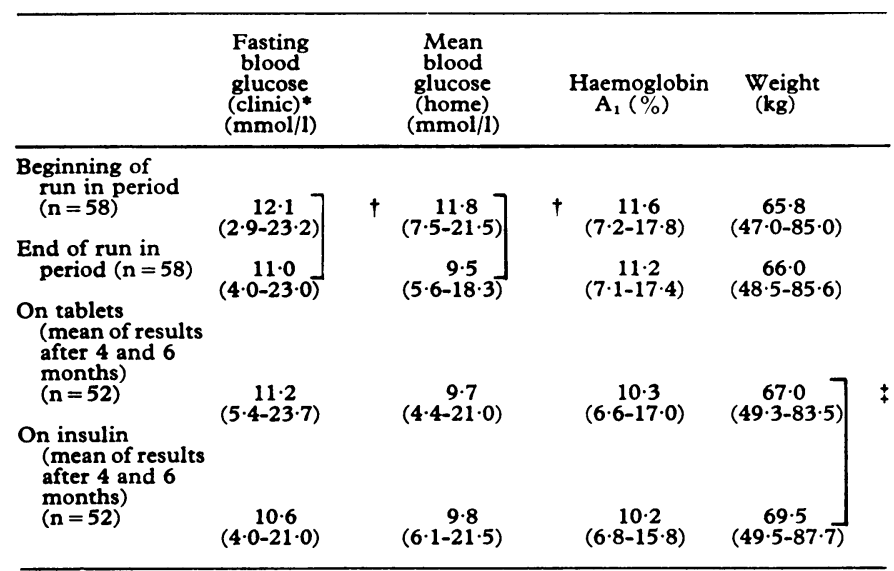

* Mean fasting blood glucose at home was $8.5 \mathrm{mmol} / 1(153 \mathrm{mg} / 100 \mathrm{ml})$ on both treatments. The higher blood glucose at clinic visits is explained by the early morning rise that occurs even without food, exaggerated by the stress and exertion of a hospital visit. ${ }^{2}$

t $<0.05 ; \pm p<0.001$ (Student's $t$ test for paired data).

Conversion: SI to traditional units-Blood glucose: $1 \mathrm{mmol} / 1 \approx 18 \mathrm{mg} / 100 \mathrm{ml}$.

TABLE II-Classification of patients according to difference in glycaemic control on insulin and tablets. Results are expressed as means (and standard deviation)

\begin{tabular}{|c|c|c|c|}
\hline & $\begin{array}{l}\text { Control better } \\
\text { on insulin }\end{array}$ & No difference & $\begin{array}{l}\text { Control better } \\
\text { on tablets }\end{array}$ \\
\hline $\begin{array}{l}\text { Numbert } \\
\text { Age (years) } \\
\text { Duration of diabetes (years) } \\
\text { Body mass index (kg/m²) } \\
\text { Daily insulin dose (units) } \\
\text { No who preferred insulin } \\
\text { No who preferred tablets }\end{array}$ & $\begin{array}{l}18 \\
59 \cdot 4 \\
8 \cdot 5 \\
23 \cdot 9 \\
32 \cdot 1 \\
9 \\
9\end{array}$ & $\begin{array}{l}18 \\
58 \cdot 8 \\
9 \cdot 5 \\
23 \cdot 4 \\
27 \cdot 8 \\
5 \\
13\end{array}$ & $\begin{array}{l}19 \\
57 \cdot 6 \\
8 \cdot 7 \\
24 \cdot 4 \\
31 \cdot 8 \\
9 \\
10\end{array}$ \\
\hline \multirow{2}{*}{$\begin{array}{l}\text { Fasting } C \text { peptide (nmol/1) } \\
\text { Fasting } C \text { peptide:fasting blood } \\
\text { glucose }\left(\times 10^{\circ}\right)\end{array}$} & $51(17)^{*}$ & $52(29)$ & $78(43)$ \\
\hline & $40(22)^{* * *}$ & $50(32)$ & $84(37)$ \\
\hline \multicolumn{4}{|l|}{$\begin{array}{l}\text { Fasting blood glucose at clinic } \\
\text { visits }(\mathrm{mmol} / 1):\end{array}$} \\
\hline $\begin{array}{l}\text { On tablets } \\
\text { On insulin } \\
\text { Mean blood glucose at home }\end{array}$ & $\begin{array}{c}13.7(3.9) * * * \\
9.6(3.3) * *\end{array}$ & $\begin{array}{l}10.9(2.4) \\
10 \cdot 3(2 \cdot 6)\end{array}$ & $\begin{array}{r}9 \cdot 2(2 \cdot 2) \\
12 \cdot 8(3 \cdot 6)\end{array}$ \\
\hline \multirow{2}{*}{$\begin{array}{l}\text { On tablets } \\
\text { On insulin } \\
\text { Haemoglobiin } A_{1}(\%): \\
\text { On tablets } \\
\text { On insulin }\end{array}$} & $\begin{array}{c}11.3(2 \cdot 6) * * * \\
9.9(2 \cdot 8)\end{array}$ & $\begin{array}{r}10.0(2.9) \\
9.8(2.3)\end{array}$ & $\begin{array}{r}8.2(2.0) \\
10.5(2.7)\end{array}$ \\
\hline & $\begin{array}{l}11.9(1 \cdot 7) * * * \\
10 \cdot 2(2 \cdot 0)\end{array}$ & $\begin{array}{l}9.7(1.5) \\
9.5(1.5)\end{array}$ & $\begin{array}{r}9 \cdot 4(1 \cdot 7) \\
11 \cdot 3(2 \cdot 2)\end{array}$ \\
\hline
\end{tabular}

†Not included are two patients who did not complete six months on insulin and the

patient who died. insulin and those better controlled on tablets; Student's $t$ test for unpaired data. Conversion: SI to traditional units-Blood glucose: $1 \mathrm{mmol} / 1 \approx 18 \mathrm{mg} / 100 \mathrm{ml}$.

\section{PEPTIDE}

Mean fasting $\mathrm{C}$ peptide concentration on tablets was $0.61 \mathrm{nmol} / \mathrm{l}$ (range $0 \cdot 15-2 \cdot 05$ ). There was no significant correlation with known duration of diabetes but $C$ peptide tended to be higher in fatter patients (correlation between $C$ peptide and body mass index $=0.36$, $\mathrm{p}<0.05)$.

Patients with low fasting $\mathbf{C}$ peptide concentrations tended to have improved control on insulin while those with high fasting $C$ peptide values tended to do better on tablets (table II). The ratio of fasting $C$ peptide to fasting blood glucose was more closely related to the difference in control on the two treatments (see figure); of the 18 patients whose control was better on insulin, 17 had a $\mathrm{C}$ peptide: glucose ratio less than $70\left(\times 10^{-9}\right)$. Of those 18 whose control was better on tablets and in whom $C$ peptide measurements were obtained, 11 had $C$ peptide:glucose ratios greater than 70 , including ail five whose control was not improved in spite of 48 units insulin daily.

\section{THE PATIENTS' CHOICE}

Twenty three patients preferred insulin and chose to continue it at the end of the trial. Thirty four preferred (and returned to) tablets. An improved sense of well being on insulin was reported by 22 patients, including three who nevertheless chose to return to tablets for other reasons. In spite of feeling better only 10 of the 22 were objectively better controlled on insulin. Only eight patients indicated that they felt better on tablets, the rest reporting no clear differences one way or the other. Convenience and dislike of injections were the main reasons for choosing tablets.

Patients who indicated a preference for insulin could not be distinguished from the rest by their age, duration of diabetes, body mass index, or any measure of diabetic control.

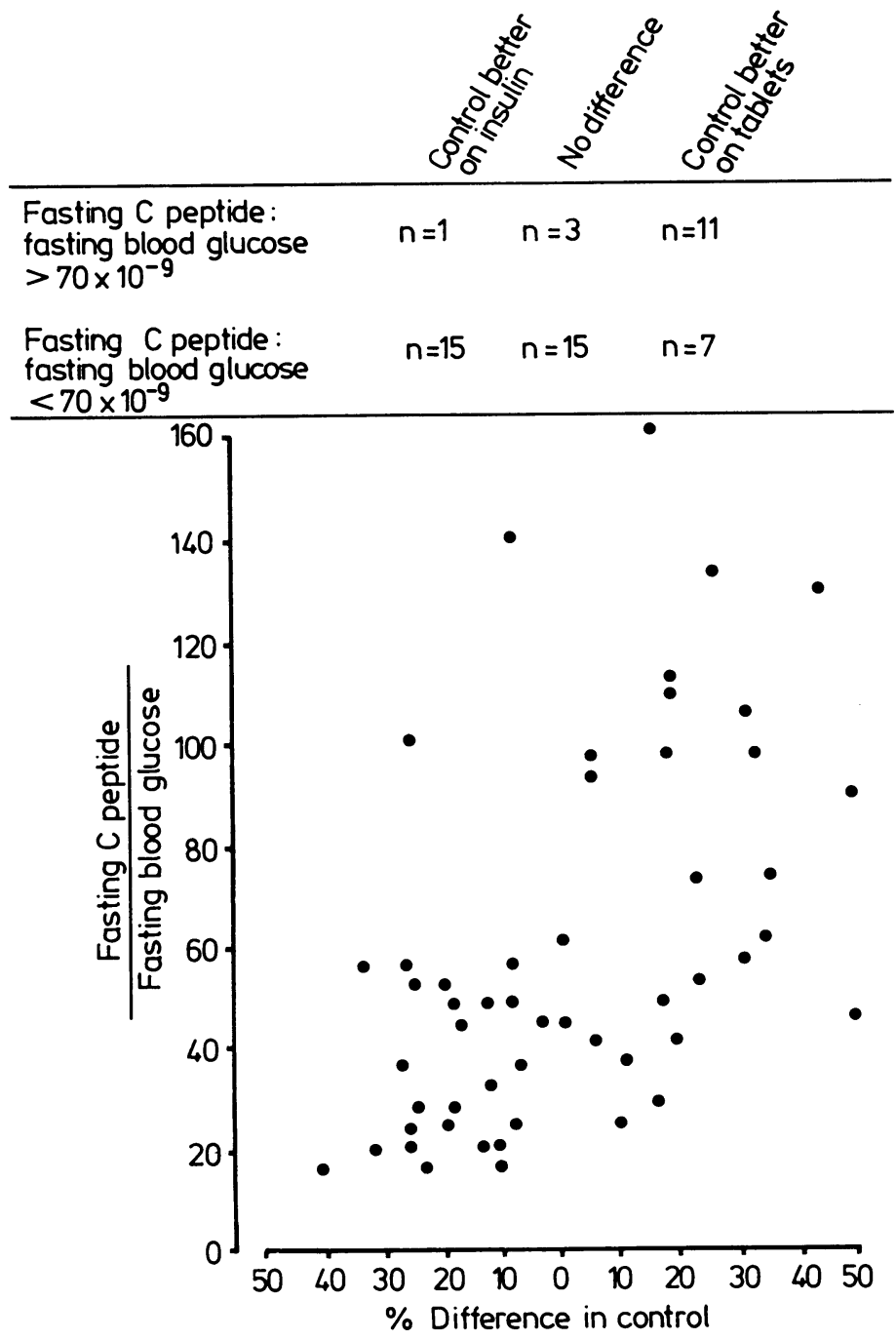

Correlation between ratio of fasting $\mathrm{C}$ peptide to glucose and difference in glycaemic control on insulin and tablets in individual patients $(r=0.58$; p $<0.001$ ).

\section{Discussion}

Absolute indications for the use of insulin are well known. They include ketosis and substantial weight loss whatever the age of the patient. ${ }^{10}$ Most patients covered by these indications have type I diabetes. The use of insulin in type II diabetes is less well defined and varies among countries and physicians. In the United States, where doubts about the safety of oral hypoglycaemic agents have restricted treatment options, a recent textbook recommends insulin "for patients who are at or below ideal body weight and in whom the fasting plasma glucose is persistently in excess of $130 \mathrm{mg} / 100 \mathrm{ml}(7 \cdot 2 \mathrm{mmol} / \mathrm{l})$ or $220 \mathrm{mg} / 100 \mathrm{ml}(12.2 \mathrm{mmol} / \mathrm{l})$ in the geriatric patient in spite of optimum dietary adherence alone or in combination with oral hypoglycaemic agents."11 In the United Kingdom insulin is usually only used in type II diabetes as a last resort; this may be because metformin (not available in the United States) offers 
a more potent oral hypoglycaemic regimen than a sulphonylurea alone. The availability of a wider range of tablets may be misleading, however, encouraging collusion between patient and physician to continue large doses of tablets even when they are clearly failing to achieve good control. Alternatively, the assumption that a switch to insulin will invariably improve control when tablets have failed has not been proved.

Our major conclusions were that insulin treatment need not be difficult or unwelcome even in elderly patients. Indeed many preferred it to tablets. But when given as a single daily dose limited to 48 units of Monotard, it did not necessarily improve diabetic control, and in some cases it even produced worse control than maximal doses of glibenclamide and metformin. There are many reports of patients more successfully controlled by tablets than by insulin. ${ }^{12-16}$ Equally other patients are very grateful when insulin is started. This diversity reflects the fact that maturity onset diabetes is not simply a state of insulin deficiency but a complex interplay of deficiency and resistance, the importance of each factor varying from patient to patient. ${ }^{2-4}$ There is accumulating evidence that oral hypoglycaemic agents work, at least in part, by reducing or overcoming insulin resistance. ${ }^{151718}$ They might therefore be most effective in patients who are relatively insulin resistant.

Like Ginsberg and Rayfield, who showed heterogeneity in type II diabetes directly by glucose and insulin infusion experiments, we were unable to identify any simple clinical features that distinguished insulin sensitive from insulin resistant patients. ${ }^{19}$ Mean duration of diabetes and mean body mass index were not measurably different in patients who were controlled more successfully by tablets and those controlled by insulin (table II).

C peptide is a convenient and reliable index of insulin secretion, insulin resistance being implied in patients with high $\mathrm{C}$ peptide concentrations. Several authors have found $\mathrm{C}$ peptide measurements useful guides to appropriate treatment. ${ }^{20-24}$ Most have used stimulation tests, $C$ peptide being measured after glibenclamide, ${ }^{20}$ glucagon, ${ }^{21}{ }^{23}$ or glucose ${ }^{23}{ }^{24}$ Welborn et al used fasting or late postprandial measurements. ${ }^{22}$ The value of random $C$ peptide measurements at clinic visits has not been investigated; these would be easy to obtain in routine practice but might be difficult to interpret. Fasting concentrations therefore seem the most useful simple index of insulin secretion. The ratio of $\mathrm{C}$ peptide to glucose was found empirically in this study to correlate best with treatment outcome, but this observation requires confirmation and explanation.

It is possible that we did not achieve better results with insulin because of the type used and the limitation of dose. Holman and Turner suggested using long acting insulin (Ultralente) to augment basal insulin supply, thus allowing endogenous insulin to cope with the blood glucose rise after meals. ${ }^{25}$ We found, however, that even when fasting blood glucose was restored to normal by Monotard, postprandial glucose excursions were sometimes extreme, indicating the need for a more rapidly acting insulin, or at least a rapid component in the insulin regimen. Scarlett et al presented evidence that intensive insulin therapy (twice daily soluble and isophane in doses of up to 154 units/day) can reverse insulin resistance, but clearly no single regimen will suffice for all cases. ${ }^{26}$ Emphasis on strict control was not appropriate for all our patients, some being quite elderly. We were interested in subjective responses to insulin and thought that patients might not have complied with a more demanding insulin regimen entailing multiple injections. Furthermore, we investigated the response to a single daily injection because in most diabetic clinics patients who have "failed" on tablets are put on to once daily insulin. An ideal insulin regimen, however, might have achieved better control, particularly in those seven patients whose $C$ peptide to glucose ratio was less than $70\left(\times 10^{-9}\right)$ but whose control in this study was better on tablets. The insulin dose was limited to an average of 24 units a day in these patients because of hypoglycaemic symptoms during the day, although fasting blood glucose remained above $6 \mathrm{mmol} / 1(108 \mathrm{mg} / 100 \mathrm{ml})$.
Weight gain is a major drawback of insulin and was our reason for limiting the insulin dose to 48 units daily. Its occurrence even in patients whose control was worse on insulin suggests that insulin has a differential influence on glucose homoeostasis (where there may be resistance to its action) and on lipid storage in adipose tissue.

Patients poorly controlled on tablets are common in all diabetic clinics. A simple insulin regimen may not help since, as we have shown, it may lead to deterioration of control. The belief, however, that insulin should be given only as a last resort because it is too difficult or unpleasant, or because once started it cannot be stopped, is clearly unfounded. Our study suggests that the quality of life of many middle aged patients will be improved by insulin and that patients whose control is poor on tablets should be given an extended trial of injections with the clear understanding that they can go back to tablets if they wish. Measurement of $C$ peptide may predict whether diabetic control is likely to improve, but when optimum control is the aim of treatment a more complex regimen of multiple injections may be required.

We thank Novo Laboratories, Basingstoke, whose financial support made this study possible; Drs S P Allison, D J Hosking, and W J Jeffcoate for allowing us to study patients under their care; our dietitian, Mrs J C Heald, for many hours of painstaking effort; Mrs $M$ Villiers, who performed the $\mathrm{HbA}_{1}$ assays; $\mathrm{Mr} \mathrm{R}$ Watts and Mr C Selby, who performed the C peptide assays; Mr R B Jones, who provided computing facilities; and Mrs S Revill, Mrs J Richards, and Mrs B Kay for typing and retyping the manuscript.

\section{References}

${ }^{1}$ Council on Scientific Affairs, American Medical Association. Hypoglycemic treatment. Guidelines for the non-insulin dependent diabetic. $\mathcal{F} A M A 1980$; 243:2078-9.

Reaven GM, Bernstein R, Davis B, Olefsky JM. Non-ketotic diabetes mellitus: insulin deficiency or insulin resistance? $A m \mathcal{F} M e d ~ 1976 ; 60: 80-8$. DeFronzo RA, Ferrannini E. The pathogenesis of non-insulin dependent diabetes. Medicine (Baltimore) 1982;61:125-40.

Turner RC, Mathews D, Holman RR, Peto J. Relative contributions of insulin deficiency and insulin resistance in maturity-onset diabetes. Lancet 1982;i:596-8. National Diabetes Data Group. Classification and diagnosis of diabetes mellitus and other categories of glucose intolerance. Diabetes $1979 ; 28: 1039-57$

Paul AA, Southgate DAT. McCance and Widdowson's The composition of foods. London: HMSO, 1978

Howe-Davies S, Holman RR, Phillips M, Turner RC. Home blood sampling for plasma glucose assay in control of diabetes. Br Med f 1978;ii:596-8.

rinder P. Determination of glucose in blood using glucose oxidase with an Heding LG. Radioimmunological determination of human C-peptide in serum. Diabetologia 1975;11:541-8

${ }^{10}$ Colwell AR. Treatment of diabetes: selection of tecnic according to severity. Diabetes 1953;2:262-7.

Galloway JA, Deshazo RD. The clinical use of insulin and the complications of insulin therapy. In: Ellenberg $M$, Rifkin $\mathrm{H}$, eds. Diabetes mellitus. Theory and practice. 3rd ed. New York: Medical Examination Publishing Co Inc, 1983. Singer DL, Stewart RC, Hurwitz D. Chlorpropamide in patients on high insulin dosage. $N$ Engl F Med $1961 ; 265: 823-6$

Segre E. Diabetes mellitus with insulin resistance: report of a case successfully treated with tolbutamide. Metabolism 1962;11:562-5.

Rendell M, Slevin D, Meltz G, Simpson J, Barquet A. A case of maturity-onset Med 1979;90:195-7.

15 Eaton RP, Galagan R, Kaufman E, Allen RC Russell L Miller F. Receptor depletion in diabetes mellitus: correction with therapy. Diabetes Care 1981;4: 299-304.

${ }^{16}$ Kromann H, Borch E, Gale EAM. Unnecessary insulin treatment for diabetes. BrMed I 1981;283:1386-8.
Britz

Feinglos NN, Lebovitz HE. Sulfonylurea treatment of insulin-independent diabetes mellitus. Metabolism 1980;29:488-94.

Kolterman OG, Prince MJ, Olefsky JM. Insulin resistance in non-insulindependent diabetes mellitus: impact of sulfonylurea agents in vivo and in vitro. Am $\mathcal{F}$ Med 1983;74:82-101.

19 Ginsberg H, Rayfield EJ. Effect of insulin therapy on insulin resistance in type II diabetic subjects. Evidence for heterogeneity. Diabetes $1981 ; 30: 739-45$.
Beischer W, Kerner W, Raptis S, Keller

Beischer W, Kerner W, Raptis S, Keller L, Beischer B, Pfeiffer EF. Insulin therapy

${ }^{21}$ Madsbad S, Krarup T, McNair P, et al. Practical clinical value of the C-peptide response to glucagon stimulation in the choice of treatment in diabetes mellitus. response to glucagon stimulation
Acta Med Scand $1981 ; 210: 153-6$.

22 Turkington RW, Estkowski A, Link M. Secretion of insulin or connecting peptide. A predictor of insulin dependence of obese "diabetics." Ann Intern Med 1982; 142:1102-5.

${ }^{23}$ Hoekstra JBL, van Rijn HJM, Thijssen JHH, Erkelens DW. C-peptide reactivity as a measure of insulin dependency in obese diabetic patients treated with insulin. Diabetes Care 1982;5:585-91.

${ }^{24}$ Welborn TA, Garcia-Webb P, Bonser AM. Basal C-peptide in the discrimination of type I from type II diabetes. Diabetes Care 1981;4:616-9.

Holman RR, Turner RC. Diabetes : the quest for basal normoglycaemia. Lancet $1977 ; \mathrm{i}: 469-74$

reverses the insulin resistan J, Olefsky JM, Kolterman OG. Insulin treatment reverses

${ }^{27}$ Holman RR, Turner RC. The basal plasma glucose: a simple relevant index of maturity-onset diabetes. Clin Endocrinol 1980;14:279-86.

(Accepted 11 April 1984) 